\title{
Nitrogen fertilization recommendation for corn cultivated under no-tillage
}

\author{
Helton de S. Silva ${ }^{1} \&$ Adailson P. de Souza ${ }^{1}$ \\ ${ }^{1}$ Universidade Federal da Paraíba/Centro de Ciências Agrárias/Programa de Pós-Graduação em Ciência do Solo. Areia, PB, Brasil. E-mail: heltonssilva@gmail.com \\ (Corresponding author) - ORCID: 0000-0003-0021-5610; adailson@cca.ufpb.br - ORCID: 0000-0003-2049-6069
}

\begin{abstract}
The amount of nitrogen $(\mathrm{N})$ suggested for corn crop must meet its demand, maximizing yield and minimizing losses. Therefore, the objective of this study was to determine the recommendation of $\mathrm{N}$ fertilization for corn grown under no-tillage, using the method that considers the availability of $\mathrm{N}$ from the soil, the $\mathrm{N}$ requirement for the crop to reach the projected yield and the $\mathrm{N}$-fertilizer recovery efficiency. The experiment consisted of four doses of $\mathrm{N}\left(0,30,70\right.$ and $\left.95 \mathrm{~kg} \mathrm{ha}^{-1}\right)$, arranged in randomized blocks, with five repetitions. N stock of $4,357.90 \mathrm{~kg} \mathrm{ha}^{-1}$ in the $0-20 \mathrm{~cm}$ soil layer provides corn plants with $52.83 \mathrm{~kg}$ of $\mathrm{N} \mathrm{ha}^{-1}$, corresponding to a mineralization coefficient of $1.2 \%$. The $\mathrm{N}$-fertilizer recovery efficiency and the harvest index show a progressive linear increase according to $\mathrm{N}$ doses. In projections of yields lower than $1,000 \mathrm{~kg} \mathrm{ha}^{-1}, \mathrm{~N}$ fertilization is not necessary; however, in corn cultivation under no-tillage aiming at yield above $5,000 \mathrm{~kg} \mathrm{ha}^{-1}$, fertilization needs to be performed with doses above $100 \mathrm{~kg}$ of N ha-1.
\end{abstract}

Key words: Zea mays, recovery efficiency, $\mathrm{N}$ stock, soil fertility

\section{Recomendação de adubação nitrogenada para o milho cultivado em plantio direto}

RESUMO: A quantidade de nitrogênio sugerida para o milho deve atender à demanda da cultura, maximizando a produtividade e minimizando as perdas. Portanto, objetivou-se com este estudo, determinar a recomendação de adubação nitrogenada para o milho cultivado em plantio direto, utilizando o método que considera a disponibilidade de $\mathrm{N}$ do solo, a necessidade de $\mathrm{N}$ para a cultura alcançar o rendimento projetado e a eficiência de recuperação do N-fertilizante. O experimento consistiu em quatro doses de N $(0,30,70$ e $95 \mathrm{~kg} \mathrm{ha}^{-1}$ ), dispostas em blocos ao acaso, com cinco repetições. O estoque de $\mathrm{N}$ de $4.357,90 \mathrm{~kg} \mathrm{ha}^{-1}$ na camada de 0 a $20 \mathrm{~cm}$ do solo, disponibiliza às plantas de milho $52,83 \mathrm{~kg} \mathrm{ha}^{-1} \mathrm{de} \mathrm{N}$, correspondente a um coeficiente de mineralização de 1,2\%. A eficiência de recuperação do $\mathrm{N}$-fertilizante e o índice de colheita têm incremento linear de acordo com as doses de $\mathrm{N}$. Em projeções de rendimentos inferiores à $1.000 \mathrm{~kg} \mathrm{ha}^{-1}$, não é necessário realizar adubação nitrogenada, no entanto, em cultivo de milho em plantio direto que vise produtividade superior a $5.000 \mathrm{~kg} \mathrm{ha}^{-1}$ é necessário realizar adubações com doses superiores a $100 \mathrm{~kg} \mathrm{ha}^{-1} \mathrm{de} \mathrm{N}$.

Palavras-chave: Zea mays, eficiência de recuperação, estoque de N, fertilidade do solo 


\section{INTRODUCTION}

Brazil is one of the largest corn producers in the world, but regional discrepancies regarding the use of cultivation practices, such as balanced mineral fertilization, implementation of irrigation, soil correction, soil conservation management system and use of varieties responsive to nitrogen fertilization (Cruz et al., 2008; Pinho et al., 2009; Santos et al., 2013), cause large difference in the average yield of this crop between the states of the federation, ranging from 302 to $8,284 \mathrm{~kg} \mathrm{ha}^{-1}$ (IBGE, 2019).

As already mentioned, supplying balanced fertilization, mainly of nitrogen $(\mathrm{N})$, is fundamental to obtain high yields in corn crop, which requires from 80 to $401 \mathrm{~kg} \mathrm{ha}^{-1}$ of $\mathrm{N}$ according to the technological level employed (Pinho et al., 2009; França et al., 2011). Another aspect that is considered about the $\mathrm{N}$ supply to corn is the efficiency of the $\mathrm{N}$-fertilizer recovery by plants, which is generally low, ranging from 30 to 80\% (Halvorson et al., 2004; Silva et al., 2006; Morris et al., 2018; Oliveira et al., 2018).

In addition to the knowledge on the $\mathrm{N}$ requirement for corn and the efficiency of $\mathrm{N}$-fertilizer recovery by plants, it is necessary to estimate the mineralization potential of soil $\mathrm{N}$, which can be determined in field experiments, integrating the crop growth factors with the $\mathrm{N}$ dynamics in a given soil-cropclimate system (Keeney, 1982).

Therefore, the objective of this study was to determine the recommendation of $\mathrm{N}$ fertilization for corn grown under no-tillage, using the method that considers the availability of $\mathrm{N}$ from the soil, the $\mathrm{N}$ requirement for the crop to reach the projected yield and the $\mathrm{N}$-fertilizer recovery efficiency.

\section{Material ANd Methods}

The experiment was conducted at the experimental farm Chã-do-Jardim, belonging to the Federal University of Paraíba, Center of Agrarian Sciences (UFPB/CCA), located at 6.97\% S latitude and $35.73^{\circ} \mathrm{W}$ longitude, in the municipality of Areia, $\mathrm{PB}$, Brazil. The climate is tropical rainy, with dry summer. The rainy season begins in January/February and ends in September, and can be advanced until October, with average annual rainfall of 1,358.4 $\mathrm{mm}$ (AESA, 2018).

This study was part of a long-term experiment with corn grown in a no-tillage system. For five years (2013 to 2017), the experiment was conducted in a randomized block design with treatments of $0,30,70$ and $95 \mathrm{~kg} \mathrm{ha}^{-1}$ of $\mathrm{N}$ always available in the same plots, with five repetitions. Potassium fertilization (56 kg ha-1 of $\mathrm{K}_{2} \mathrm{O}$ ) and phosphate fertilization $\left(80 \mathrm{~kg} \mathrm{ha}^{-1}\right.$ of
$\mathrm{P}_{2} \mathrm{O}_{5}$ in the form of single superphosphate) were the same for all treatments, entirely applied as basal along with 30\% of the $\mathrm{N}$ dose. The remaining $\mathrm{N}$ dose was applied broadcast as topdressing, close to the sowing line, 45 days after corn sowing.

The variety AG 1051 was sown at the spacing of $1.00 \times 0.20 \mathrm{~m}$, forming a stand of 50,000 plants $\mathrm{ha}^{-1}$. Each experimental unit was composed of seven planting rows with $10 \mathrm{~m}$ in length, and the usable area consisted of $40 \mathrm{~m}^{2}$ of the central part of each plot. The soil of the experimental area is classified as Oxisol (USDA, 2015), with sandy clay texture in the $0-20 \mathrm{~cm}$ layer, with $558 \mathrm{~g} \mathrm{~kg}^{-1}$ of sand, $30 \mathrm{~g} \mathrm{~kg}^{-1}$ of silt and $412 \mathrm{~g} \mathrm{~kg}^{-1}$ of clay.

Corn sowing was carried out in straw, 30 days after glyphosate was applied to eliminate weeds. For this, $10-\mathrm{cm}$ deep furrows were opened and received basal fertilization and then corn seeds, taking care to cover the fertilizer with soil to avoid direct contact with the seed. At 40 days after sowing, weeds were mechanically controlled, and then the fertilizer was applied as topdressing.

For the present study, only the response of the crop in 2017 was considered. During the corn cycle (04/12/2017 to $07 / 31 / 2017$ ), there was a regular distribution of rainfall, with a water deficit of only $4.45 \mathrm{~mm}$ in the second 10 -day period of May (Figure 1).

In each plot of the experimental area, soil sampling was performed with Dutch auger in the $0-20 \mathrm{~cm}$ layer, and three simple samples were collected to form a composite sample, in order to perform fertility analysis according to the methodology recommended by EMBRAPA (1997) (Table 1).

To determine the mineralization potential of soil N, it was necessary to know the soil N stock (NSc) and the amount of $\mathrm{N}$ extracted by the plants (NEc) in the plots without fertilization

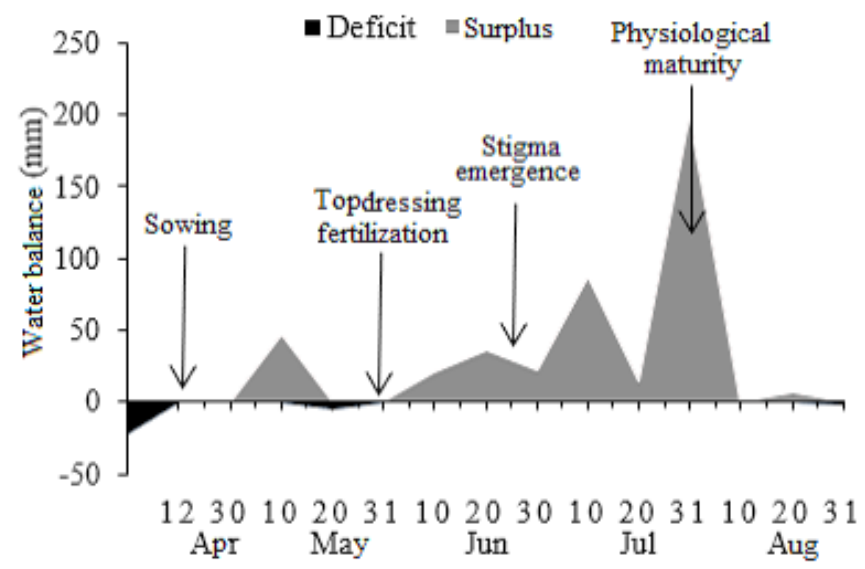

Figure 1. Normal 10-day period water balance during the corn cycle in 2017

Table 1. Soil fertility before experiment installation and after five years of cultivation

\begin{tabular}{|c|c|c|c|c|c|c|c|c|c|}
\hline \multirow{2}{*}{ Treatments } & \multirow{2}{*}{$\begin{array}{c}\mathrm{pH} \\
\mathrm{H}_{2} \mathrm{O}_{(1: 2.5)}\end{array}$} & $\mathbf{P}$ & K & $\mathrm{Na}$ & $\mathrm{Ca}$ & $\mathrm{Mg}$ & $\overline{A l}$ & $\mathrm{H}+\mathrm{Al}$ & \multirow{2}{*}{$\begin{array}{c}\mathrm{OC} \\
\left(\mathrm{g} \mathrm{kg}^{-1}\right)\end{array}$} \\
\hline & & \multicolumn{2}{|c|}{$\left.(\mathrm{mg} \mathrm{dm})^{-3}\right)$} & \multicolumn{5}{|c|}{$\left(\mathrm{cmol}_{\mathrm{c}} \mathrm{dm}^{-3}\right)$} & \\
\hline & \multicolumn{9}{|c|}{2013 - Before experiment installation } \\
\hline- & 5.65 & 3.66 & 17.96 & 0.06 & 1.40 & 1.20 & 0.55 & 8.74 & 16.50 \\
\hline & \multicolumn{9}{|c|}{2017 - Five years after experiment installation } \\
\hline 0 & 5.28 & 8.13 & 30.68 & 0.08 & 1.66 & 1.41 & 0.34 & 8.10 & 17.92 \\
\hline 30 & 5.32 & 9.11 & 35.54 & 0.05 & 1.78 & 1.39 & 0.32 & 8.38 & 19.10 \\
\hline 70 & 5.10 & 5.24 & 35.31 & 0.06 & 1.32 & 1.15 & 0.51 & 9.73 & 19.72 \\
\hline 95 & 5.20 & 10.54 & 39.95 & 0.07 & 1.70 & 1.37 & 0.35 & 9.01 & 18.98 \\
\hline
\end{tabular}

P, K, Na - Mehlich extractant 1; H + Al - 0.5 M calcium acetate extractant, pH 7.2; Al, Ca, Mg - $1 \mathrm{M} \mathrm{KCl} \mathrm{extractant;} \mathrm{OC} \mathrm{-} \mathrm{Organic} \mathrm{carbon} \mathrm{-} \mathrm{Walkley-Black}$ 
(control). Initially, soil sampling was performed at the end of the corn cycle, and soil $\mathrm{N}$ content was analyzed according to the Kjeldahl method (Tedesco et al., 1995) and soil density by the volumetric ring method (EMBRAPA, 1997), at two depths (010 and $10-20 \mathrm{~cm}$ ). Finally, N stock (NS) was obtained by Eq. 1:

$$
\begin{aligned}
\mathrm{NS} & =[\mathrm{BD}(0-10) \cdot \operatorname{STNC}(0-10) \cdot 1000]+ \\
& +[\operatorname{BD}(10-20) \cdot \operatorname{STNC}(10-20) \cdot 1000]
\end{aligned}
$$

where:

NS - soil total $\mathrm{N}$ stock, $\mathrm{kg} \mathrm{ha}^{-1}$;

$\mathrm{BD}_{(0-10)}$ and $\mathrm{BD}_{(10-20)}$ - soil bulk density $\left(\mathrm{kg} \mathrm{dm}^{-3}\right)$ from 0 to 10 and 10 to $20 \mathrm{~cm}$ depth, respectively; and,

STNC $_{(0-10)}$ and STNC ${ }_{(10-20)}$ - soil total $\mathrm{N}$ content $\left(\mathrm{g} \mathrm{kg}^{-1}\right)$ from 0 to 10 and 10 to $20 \mathrm{~cm}$ depth, respectively.

The amount of $\mathrm{N}$ extracted (NE) by corn plants was determined from the sampling of three plants per experimental unit, 110 days after sowing, in the usable area. After sampling, the straw (leaves, stem and tassel) and the ear (straw, cob and grain) were fractionated. Plants were dried in a forced air circulation oven at $65 \pm 5^{\circ} \mathrm{C}$ for 72 hours. Subsequently, the dry mass of each part was determined on a precision digital scale, being extrapolated to $\mathrm{kg} \mathrm{ha}^{-1}$, considering the stand of 45,000 plants ha-1.

After measuring the dry mass, the total $\mathrm{N}$ content was determined in each fraction of the plant, according to the methodology proposed by Tedesco et al. (1995). The $\mathrm{N}$ content in the total dry mass of corn was obtained by Eq. 2:

$$
\mathrm{NTDM}=\sum\left(\frac{\mathrm{DMi}}{\mathrm{TDM}}\right) \cdot \mathrm{NCi}
$$

where:

NTDM - N content in total dry mass, \%;

DMi - dry mass of the constituent part of the plant, $\mathrm{kg} \mathrm{ha}^{-1}$; TDM - total dry mass, $\mathrm{kg} \mathrm{ha}^{-1}$;

$\mathrm{NCi}$ - N content of the constituent part of the plant, \%; and,

i - parts of the plant (leaf, stem, tassel, straw, cob and grain).

After obtaining the plant dry mass production and $\mathrm{N}$ content, the amount of $\mathrm{N}$ extracted by the corn plants was determined using Eq. 3:

$$
\mathrm{NE}=\frac{\mathrm{NTDM} \cdot \mathrm{TDM}}{100}
$$

where:

$\mathrm{NE}$ - amount of $\mathrm{N}$ extracted by corn plants, $\mathrm{kg} \mathrm{ha}^{-1}$;

NTDM - N content in total dry mass, \%; and,

TDM - total dry mass, $\mathrm{kg} \mathrm{ha}^{-1}$.

With the values $\mathrm{N}$ extraction and $\mathrm{N}$ stock of the treatment without fertilization, the soil $\mathrm{N}$ mineralization coefficient (Amado \& Mielniczuk, 2000) was obtained by Eq. 4:

$$
\mathrm{K} 1=\frac{\mathrm{NEc}}{\mathrm{NSc}}
$$

where:

K1 - soil N mineralization coefficient;

$\mathrm{NEc}$ - N extraction by corn shoots in the control treatment, $\mathrm{kg} \mathrm{ha}^{-1}$; and,

$\mathrm{NSc}$ - N stock in control soil in the $0-20 \mathrm{~cm}$ layer, $\mathrm{kg} \mathrm{ha}^{-1}$.

The amount of nitrogen available for corn (AN) is equal to the mineralization potential of soil $\mathrm{N}$, because the fallow period in each interval between agricultural years is considered null for the mineralization or immobilization of $\mathrm{N}$, according to Amado \& Mielniczuk (2000) (Eq. 5).

$$
\mathrm{AN}=\mathrm{NS} \cdot \mathrm{K} 1
$$

where:

AN $-\mathrm{N}$ available in soil, $\mathrm{kg} \mathrm{ha}^{-1}$;
$\mathrm{NS}$ - soil N stock in the $0-20 \mathrm{~cm}$ layer, $\mathrm{kg} \mathrm{ha}^{-1}$; and,
$\mathrm{K} 1$ - mineralization coefficient.

The $\mathrm{N}$ requirement by corn crop was established based on the $\mathrm{N}$ content in the total dry mass of corn (NTDM) and by the projected yield (PY), considering the harvest index (HI) to achieve maximum grain yield. Thus, the harvest index was determined by Eq. 6:

$$
\mathrm{HI}=\frac{\mathrm{MG}}{\mathrm{TDM}}
$$

where:

HI - Harvest index;

GM - dry mass of grains, $\mathrm{kg} \mathrm{ha}^{-1}$; and,

TDM - total dry mass of corn, $\mathrm{kg} \mathrm{ha}^{-1}$.

The $\mathrm{N}$ requirement (NR) for corn crop was estimated by Eq. 7:

$$
\mathrm{NR}=\frac{\mathrm{NTDM} \cdot\left(\frac{\mathrm{PY}}{\mathrm{HI}}\right)}{100}
$$

where:

NR - N requirement for the crop, $\mathrm{kg} \mathrm{ha}^{-1}$;

NTDM - N content in total dry mass, \%;

PY - projected yield, $\mathrm{kg} \mathrm{ha}^{-1}$; and,

HI - harvest index.

Plant efficiency in the recovery of $\mathrm{N}$-fertilizer was obtained by Eq. 8 :

$$
\mathrm{NRE}=\frac{\mathrm{NEf}-\mathrm{NEc}}{\mathrm{NAF}} \cdot 100
$$

where:

$\mathrm{NRE}$ - N-fertilizer recovery efficiency, \%;

$\mathrm{NEf}$ - amount of $\mathrm{N}$ extracted by plants subjected to fertilization, $\mathrm{kg} \mathrm{ha}^{-1}$;

$\mathrm{NEc}$ - amount of $\mathrm{N}$ extracted by control plants, $\mathrm{kg} \mathrm{ha}^{-1}$; and, $\mathrm{NAF}$ - amount of $\mathrm{N}$ applied via fertilization, $\mathrm{kg} \mathrm{ha}^{-1}$. 
The Eqs. 5, 7 and 8 were used to obtain Eq. 9, employed to calculate the $\mathrm{N}$ recommendation for corn (Amado \& Mielniczuk, 2000).

$$
\mathrm{ND}=\frac{\mathrm{NR}-\mathrm{NAv}}{\mathrm{NRE}} \cdot 100
$$

where:

ND - N dose recommended for the crop, $\mathrm{kg} \mathrm{ha}^{-1}$;

$\mathrm{NR}$ - N requirement for the crop, $\mathrm{kg} \mathrm{ha}^{-1}$;

$\mathrm{NAv}$ - amount of $\mathrm{N}$ available in the soil, $\mathrm{kg} \mathrm{ha}^{-1}$; and,

$\mathrm{NRE}$ - N-fertilizer recovery efficiency, \%.

In the preliminary data analysis, Pearson's normality and correlation test were performed for the response variables, and the homogeneity of variances was evaluated (SAS ${ }^{\circ}$ University Edition, 2018). Subsequently, the data were subjected to analysis of variance and of regression, selecting the significant polynomial models $(\mathrm{p} \leq 0.05)$ with the best fit $\left(\mathrm{R}^{2}\right)$, using the program Sisvar 5.6 (Ferreira, 2011).

\section{Results AND Discussion}

Nitrogen doses did not affect its stock in the soil, which was equal to $4,357.90 \mathrm{~kg} \mathrm{ha}^{-1}$ in the $0-20 \mathrm{~cm}$ layer (Figure 2).

Even if the soil has a large amount of $\mathrm{N}$, it is difficult to completely meet the requirements of the crops, as the mineralization process that converts the organic $\mathrm{N}$ into mineral $\mathrm{N}\left(\mathrm{NH}_{4}^{+}\right.$and $\left.\mathrm{NO}_{3}^{-}\right)$occurs slowly during the year (Schimel \& Bennett, 2004). Several factors are determinant in the mineralization rate of soil $\mathrm{N}$, especially the nature of soil organic fractions, $\mathrm{N}$ and $\mathrm{C}$ contents, $\mathrm{C} / \mathrm{N}$ ratio, and soil and crop management system (Alves et al., 1999; Amado \& Mielniczuk, 2000; Marques et al., 2000).

The method used in this study to determine the mineralization of $\mathrm{N}$ in the soil integrates the crop growth factors with the $\mathrm{N}$ dynamics in the soil-plant-atmosphere system, thus considering the different elements that interfere in $\mathrm{N}$ mineralization rate (Keeney, 1982). The amount of $\mathrm{N}$

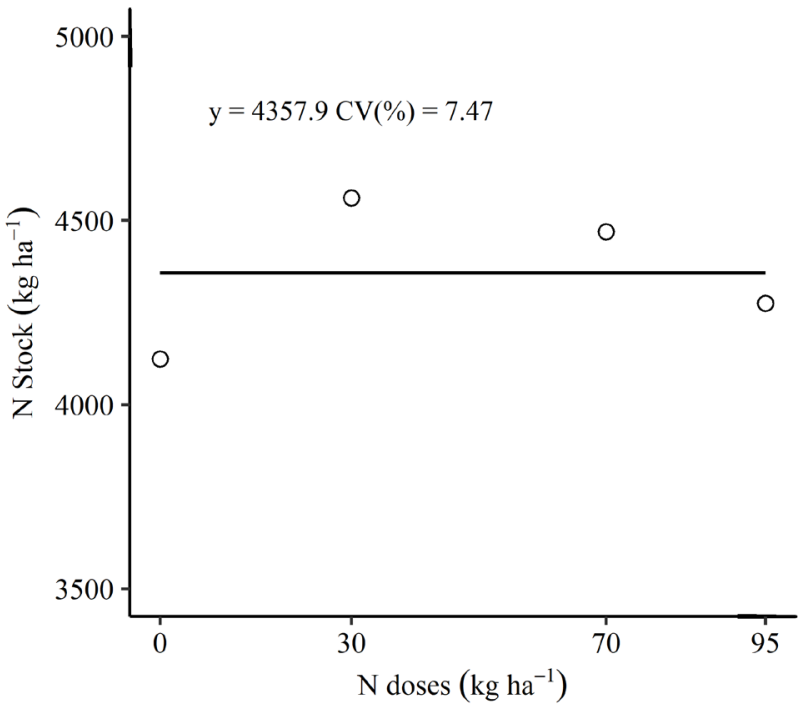

Figure 2. $\mathrm{N}$ stock in soil cultivated with corn in function of $\mathrm{N}$ doses under no-tillage system mineralized by soil microbial communities during the corn cycle was $52.83 \mathrm{~kg} \mathrm{ha}^{-1}$, which corresponds to the amount of $\mathrm{N}$ extracted by corn plants in the plot without fertilization (Figure 3).

The application of increasing doses of $\mathrm{N}$ promoted linear increment in $\mathrm{N}$ extraction by corn plants, reaching $114.95 \mathrm{~kg} \mathrm{ha}^{-1}$ (Figure 3). The same behavior was observed for corn dry mass (Figure 3), with maximum total dry mass production of $10,875.50$ and grain dry mass of $5,684.78 \mathrm{~kg} \mathrm{ha}^{-1}$. N extraction is a result of dry mass production, with a high correlation between the two variables (Figure 4).

The soil $\mathrm{N}$ mineralization coefficient (K1) obtained in this study was equal to $1.2 \%$, and this result corroborates the value obtained by Amado \& Mielniczuk (2000), which was $1.1 \%$ for the same cultivation system used in the present study. Studies with soil incubation have found that Brazilian soils have from 0.68 to $13.9 \%$ of $\mathrm{N}$ mineralization compared to the total $\mathrm{N}$ contained in the soil (Parentoni et al., 1988; Camargo et al., 1997; Alves et al., 1999).

The $\mathrm{N}$ requirement for corn crop depends on the projected yield and on the $\mathrm{N}$ content in the dry mass. Under modest conditions with low production potential, corn absorbs around $80 \mathrm{~kg} \mathrm{ha}^{-1}$ of $\mathrm{N}$; however, under conditions that enable the crop
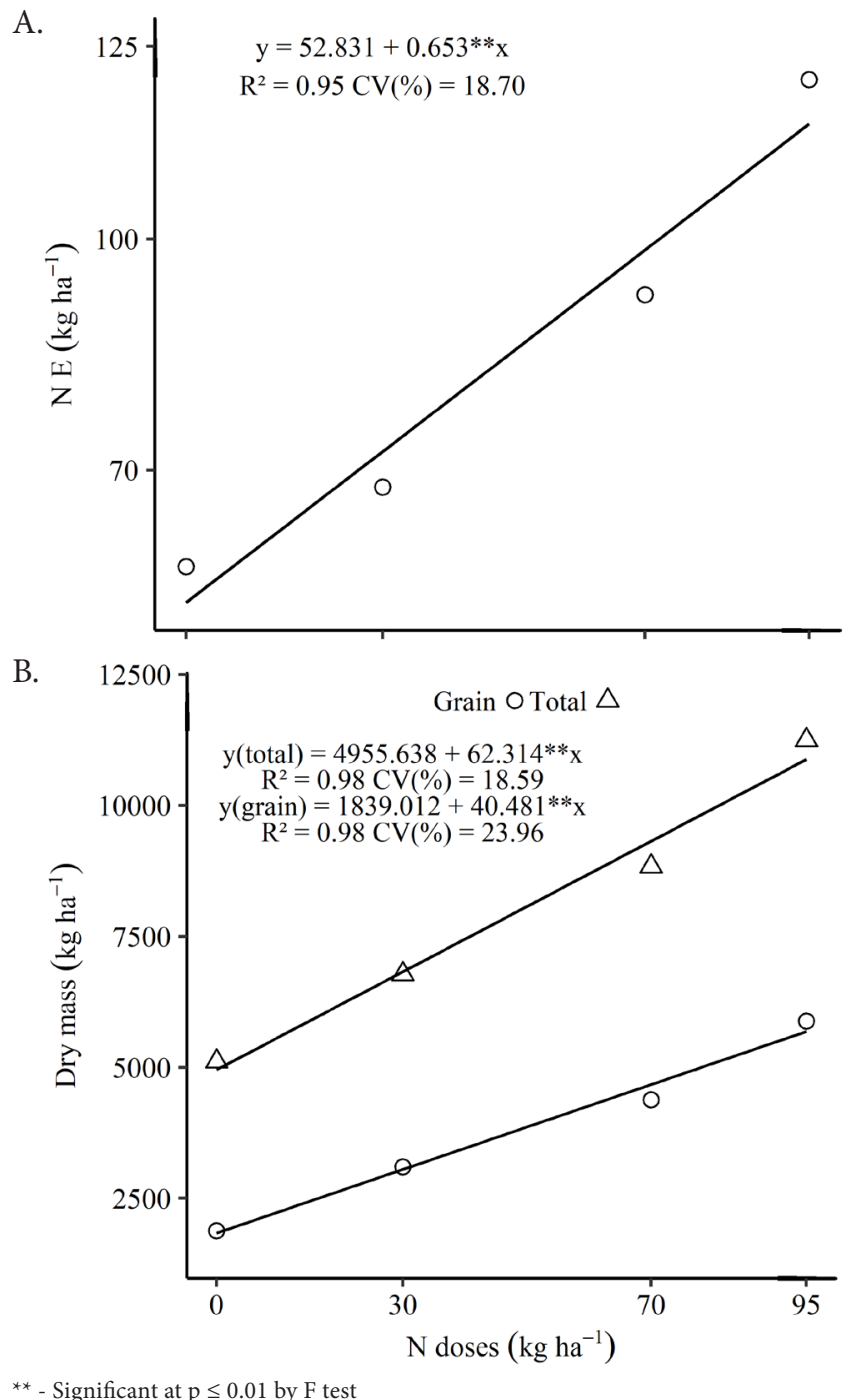

Figure 3. Nitrogen extracted (NE) (A) and total and grain dry mass (B) of corn in function of $\mathrm{N}$ doses in no-tillage system 


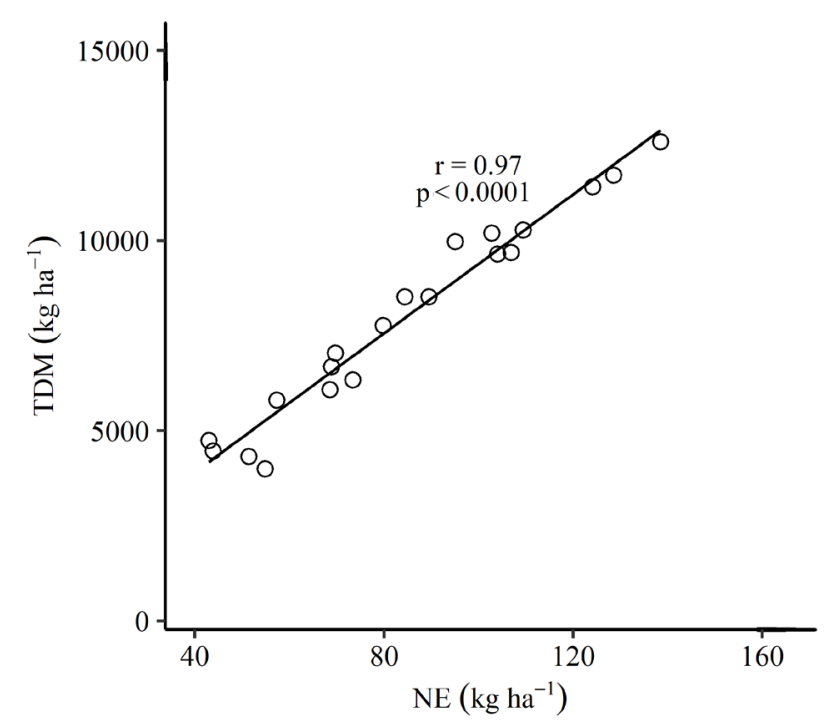

Figure 4. Correlation between total dry mass (TDM) and amount of $\mathrm{N}$ extracted (NE) by corn plants under no-tillage system

to reach high yields, corn can absorb up to $401 \mathrm{~kg} \mathrm{ha}^{-1}$ of $\mathrm{N}$ (Pinho et al., 2009; França et al., 2011).

Several studies have demonstrated that there is an optimal concentration of $\mathrm{N}$ in the dry mass of corn for maximum physical and/or economic yield. Stanford (1973) compiled information from several experiments in the USA and found that the maximum yield of corn is associated with a $\mathrm{N}$ concentration of $1.2 \%$ in dry mass. Amado \& Mielniczuk (2000), analyzing the economic and environmental aspects, considered as $0.9 \%$ the critical concentration of $\mathrm{N}$ to achieve maximum yield. In this study, the $\mathrm{N}$ concentration in the dry mass of corn was $1.064 \%$, with no difference between fertilization treatments (Figure 5).

Even with greater $\mathrm{N}$ extraction, promoted by the higher availability of this nutrient at the highest doses, there was no correlation between the $\mathrm{N}$ concentration in the dry mass and the relative dry mass production $(\mathrm{r}=-0.1573, \mathrm{p}=0.5078)$, as revealed by Stanford (1973) and Amado \& Mielniczuk (2000). What may have occurred is the dilution effect of the nutrient (Janssen et al., 1990), caused by higher biomass production.

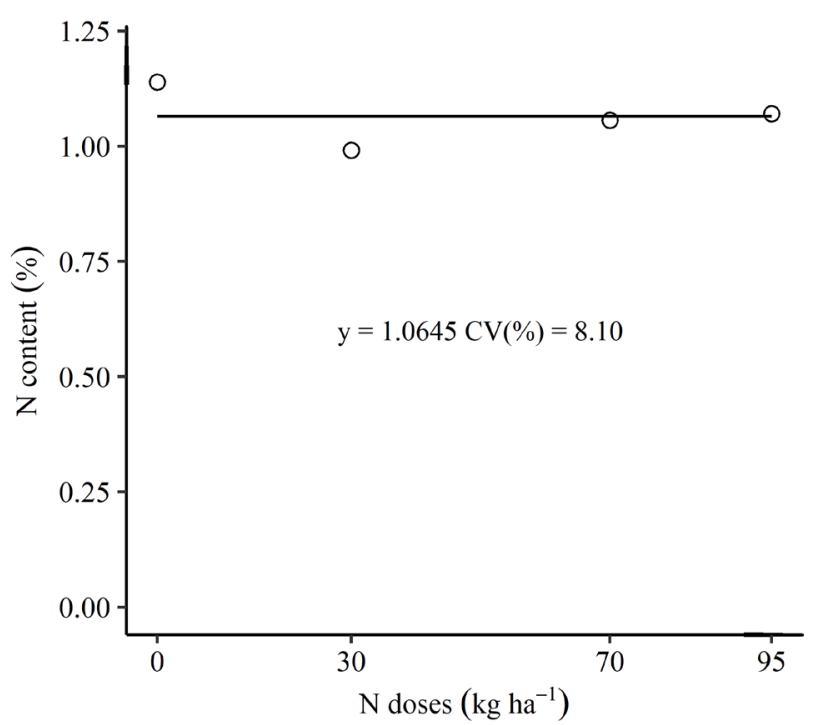

Figure 5. $\mathrm{N}$ content in the total dry mass of corn in function of $\mathrm{N}$ doses under no-tillage system
The harvest index can be reliably used to estimate the total dry mass production from grain production. For corn, 0.5 is usually considered as harvest index (Stanford, 1973; Morris et al., 2018). However, this value can range from 0.1 to 0.72 , depending on the cultivar, nutrient availability and edaphoclimatic conditions (Amado \& Mielniczuk, 2000; Dourado Neto \& Fancelli, 2000). The harvest index obtained in the present study showed increasing linear behavior as a function of $\mathrm{N}$ availability to plants, ranging from 0.38 to 0.53 (Figure 6).

Generally, under conditions of low $\mathrm{N}$ availability, grain production is more compromised to the detriment of plant residue production, with an increase in the harvest index as the availability of this nutrient increases. Amado \& Mielniczuk (2000) reported that under high availability of $\mathrm{N}$ the harvest index can reach 0.72. Gava et al. (2010) found that the harvest index ranged from 0.45 to 0.49 , regardless of $\mathrm{N}$ availability. Andrade et al. (2014) reported that the harvest index showed a quadratic behavior with the increase in $\mathrm{N}$ doses, with a maximum point of 0.44 at the $\mathrm{N}$ dose of $131 \mathrm{~kg} \mathrm{ha}^{-1}$.

The estimate of $\mathrm{N}$-fertilizer recovery is an approximate measurement of the recovery of $\mathrm{N}$ fertilizers by plants, given the high complexity of the processes and the amount of factors that control it. $\mathrm{N}$-fertilizer recovery efficiency (NRE) may vary according to fertilizer source, method and time of application, and site-specific edaphoclimatic factors. According to Morris et al. (2018), the main limiting factor for variability in NRE is the occurrence of rains after fertilizer application.

In the present study, the $\mathrm{N}$-fertilizer recovery efficiency ranged from 36.5 to $65 \%$ for $\mathrm{N}$ doses from 30 to $95 \mathrm{~kg} \mathrm{ha}^{-1}$ (Figure 7). The higher recovery efficiency at the highest $\mathrm{N}$ doses is due to the increase in corn root mass (Silva et al., 2018).

Based on these results, $\mathrm{N}$ doses above $100 \mathrm{~kg} \mathrm{ha}^{-1}$ are recommended for grain yields greater than $5,000 \mathrm{~kg} \mathrm{ha}^{-1}$ (Table 2). For a good estimation of doses, the recommendation method used suggests including the amount of $\mathrm{N}$ available in the soil; the $\mathrm{N}$ requirement by the crop to achieve the projected yield, and the expected $\mathrm{N}$-fertilizer recovery efficiency.

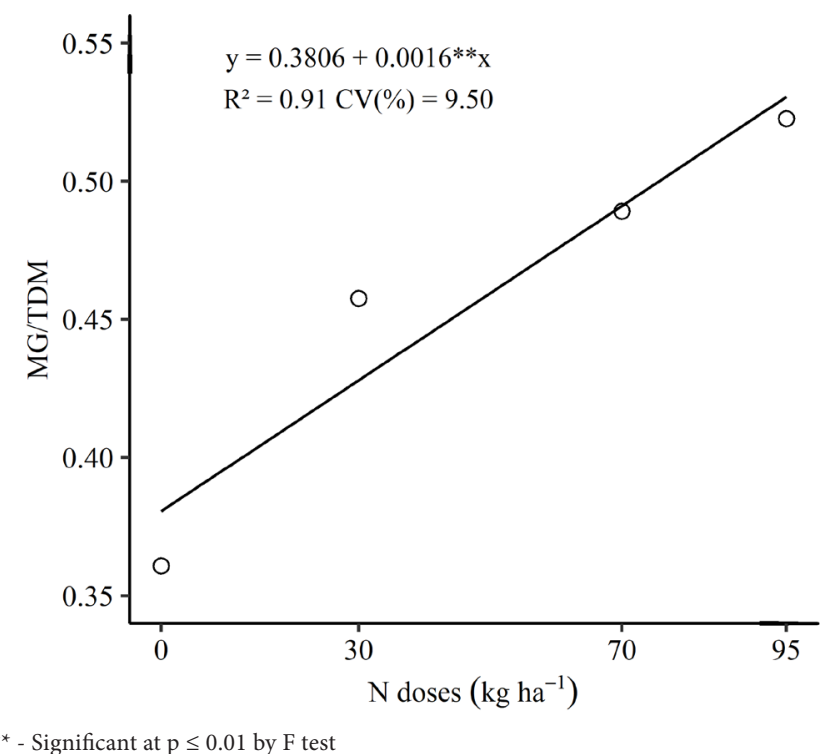

Figure 6. Harvest index (HI) of corn in function of $\mathrm{N}$ doses under no-tillage system 


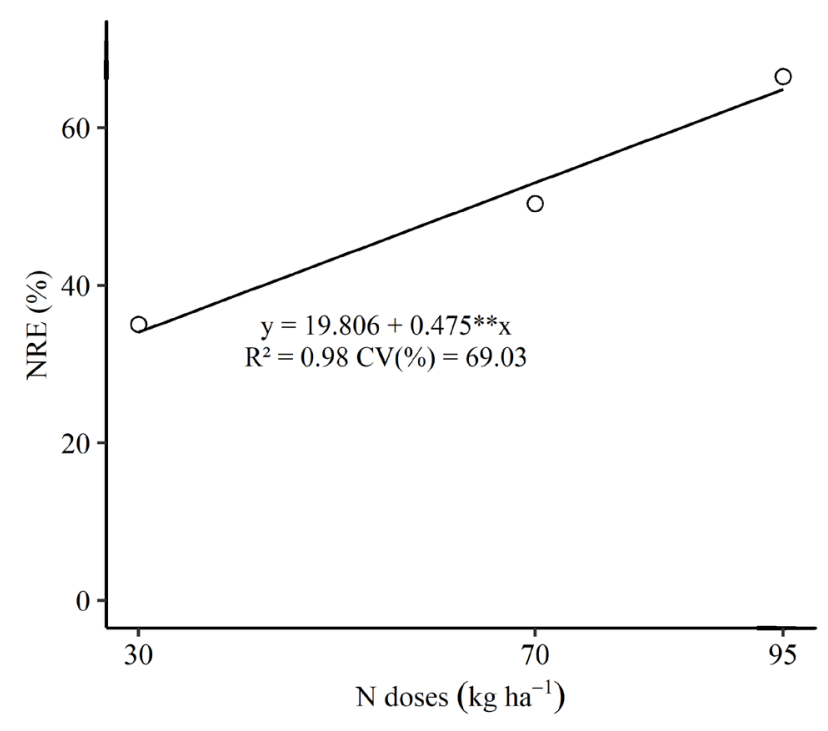

${ }^{*}$ Significant at $\mathrm{p} \leq 0.01$ by $\mathrm{F}$ test

Figure 7. N-fertilizer recovery efficiency (NRE) in corn in function of $\mathrm{N}$ doses under no-tillage system

Table 2. Recommendation of nitrogen fertilization for corn cultivated in no-tillage system

\begin{tabular}{lcccccccc}
\hline & \multicolumn{8}{c}{ Projected yield, $\mathrm{kg} \mathrm{ha}^{-1}(\mathbf{x} \mathbf{1 , 0 0 0})$} \\
\cline { 2 - 9 } & $\mathbf{1}$ & $\mathbf{2}$ & $\mathbf{3}$ & $\mathbf{4}$ & $\mathbf{5}$ & $\mathbf{6}$ & $\mathbf{7}$ & $\mathbf{8}$ \\
HI & 0.38 & 0.39 & 0.43 & 0.47 & 0.51 & 0.53 & 0.53 & 0.53 \\
NRE (\%) & - & 37 & 37 & 45 & 57 & 65 & 65 & 65 \\
ND (kg ha-1) & 0 & 6 & 60 & 85 & 93 & 105 & 135 & 166 \\
\hline
\end{tabular}

HI - Harvest index; NRE - N-fertilizer recovery efficiency; ND - Recommended N dose

Recommendation methods that consider only the requirement of the crop and fertilization efficiency, ignoring the availability of the element in the soil, give rise to a certain degree of empiricism at the moment of defining the dose. Therefore, the proposed recommendation method is more appropriate because it considers other variables, such as the supply of $\mathrm{N}$ by the soil to corn plants.

\section{Conclusions}

1. Soil $\mathrm{N}$ stock of $4,357.90 \mathrm{~kg} \mathrm{ha}^{-1}$ in the $0-20 \mathrm{~cm}$ layer enables the extraction of $52.83 \mathrm{~kg} \mathrm{ha}^{-1}$ of $\mathrm{N}$ by corn plants, resulting in a mineralization coefficient of $1.2 \%$.

2. Harvest index and $\mathrm{N}$-fertilizer recovery efficiency are variable according to $\mathrm{N}$ availability.

3. The highest recovery efficiency of $\mathrm{N}$-fertilizer is obtained at the $\mathrm{N}$ dose of $95 \mathrm{~kg} \mathrm{ha}^{-1}$.

4. For corn crops in no-tillage system aiming at yields above $5,000 \mathrm{~kg} \mathrm{ha}^{-1}, \mathrm{~N}$ doses above $100 \mathrm{~kg} \mathrm{ha}^{-1}$ should be applied and fertilization is not necessary for yields below $1,000 \mathrm{~kg} \mathrm{ha}^{-1}$.

\section{Literature Cited}

AESA - Agência Executiva de Gestão das Águas. Climatologia. Available at: <http://www.aesa.pb.gov.br/aesa-website/ meteorologia-chuvas/climatologia/>. Accessed in: Mar. 2018.

Alves, G. D.; Sampaio, E. V. S. B.; Salcedo, I. H.; Silva, V. M. Potencial de mineralização de $\mathrm{N}$ e de $\mathrm{C}$ em vinte solos de Pernambuco. Revista Brasileira de Ciência do Solo, v.23, p.245-256, 1999. https://doi.org/10.1590/S0100-06831999000200008
Amado, T. J. C.; Mielniczuk, J. Estimativa da adubação nitrogenada para o milho em sistemas de manejo e culturas de cobertura do solo. Revista Brasileira de Ciências do Solo, v.24, p.553-560, 2000. https://doi.org/10.1590/S0100-06832000000300009

Andrade, F. R.; Petter, F. A.; Nóbrega, J. C. A.; Pacheco, L. P.; Zuffo, A. M. Desempenho agronômico do milho a doses e épocas de aplicação de nitrogênio no Cerrado piauiense. Revista de Ciências Agrárias, v.57, p.358-366, 2014. https://doi.org/10.4322/rca.1295

Camargo, F. A. O.; Gianello, C.; Vidor, C. Potencial de mineralização do nitrogênio em solos do Rio Grande do Sul. Revista Brasileira de Ciência do Solo, v.21, p.575-579, 1997. https://doi.org/10.1590/ S0100-06831997000400007

Cruz, S. C. S.; Pereira, F. R. da S.; Santos, J. R.; Albuquerque, A. W. de; Pereira, R. G. Adubação nitrogenada para o milho cultivado em sistema plantio direto, no Estado de Alagoas. Revista Brasileira de Engenharia Agrícola e Ambiental, v.12, p.62-68, 2008. https:// doi.org/10.1590/S1415-43662008000100009

Dourado Neto, D.; Fancelli, A. L. Produção de milho. Guaíba: Agropecuária, 2000. 360p.

EMBRAPA - Empresa Brasileira de Pesquisa Agropecuária. Manual de métodos de análise de solo. 2. ed. Rio de Janeiro: Embrapa Solos, 1997. 212p.

Ferreira, D. F. Sisvar: A computer statistical analysis system. Ciência e Agrotecnologia, v.35, p.1039-1042, 2011. https://doi. org/10.1590/S1413-70542011000600001

França, S.; Mielniczuk, J.; Rosa, L. M. G.; Bergamaschi, H.; Bergonci, J. I. Nitrogênio disponível ao milho: Crescimento, absorção e rendimento de grãos. Revista Brasileira de Engenharia Agrícola e Ambiental, v.15, p.1143-151, 2011. https://doi.org/10.1590/ S1415-43662011001100006

Gava, G. J. de C.; Oliveira, M. W. de; Silva, M. de A.; Jerônimo, E. M.; Cruz, J. C. S.; Trivelin, P. C. O. Produção de fitomassa e acúmulo de nitrogênio em milho cultivado com diferentes doses de ${ }^{15} \mathrm{~N}$-uréia. Semina: Ciências Agrárias, v.31, p.851-862, 2010. https://doi.org/10.5433/1679-0359.2010v31n4p851

Halvorson, A. D.; Nielsen, D. C.; Reule, C. A. Nitrogen fertilization and rotation effects on no-till dryland wheat production. Agronomy Journal, v.96, p.1196-1201, 2004. https://doi. org/10.2134/agronj2004.1196

IBGE - Instituto Brasileiro de Geografia e Estatística. Produção agrícola municipal. Available at: <https://sidra.ibge.gov.br/ tabela/5457>. Accessed in: Jan. 2019.

Janssen, B. H.; Guiking, F. C. T.; Eijk, D. van der; Smaling, E. M. A.; Wolf, J.; Reuler, H. van. A system for quantitative evaluation of the fertility of tropical soils (QUEFTS). Geoderma, v.46, p.299318, 1990. https://doi.org/10.1016/0016-7061(90)90021-Z

Keeney, D. R. Nitrogen management for maximum efficiency and minimum pollution. In: Stevenson, F. J. (ed.). Nitrogen in agricultural soils. Madison: Soil Science Society of America, 1982. Cap. 3, p.605-649. https://doi.org/10.2134/ agronmonogr22.c16

Marques, T. C. L. L. de S. e M.; Vasconcellos, C. A.; Pereira Filho, I.; França, G. E. de; Cruz, J. C. Envolvimento de dióxido de carbono e mineralização de nitrogênio em Latossolo vermelhoescuro com diferentes manejos. Pesquisa Agropecuária Brasileira, v.35, p.581-589, 2000. https://doi.org/10.1590/S0100204X2000000300014 
Morris, T. F.; Murrell, T. S.; Beegle, D. B.; Camberato, J. J.; Ferguson, R. B.; Grove, J.; Ketterings, Q.; Kyveryga, P. M.; Laboski, C. A. M.; McGrath, J. M.; Meisinger, J. J.; Melkonian, J.; Moebius-Clune, B. N.; Nafziger, E. D.; Osmond, D.; Sawyer, J. E.; Scharf, P. C.; Smith, W.; Spargo, J. T.; Es, H. M. van; Yang, H. Strengths and limitations of nitrogen rate recommendations for corn and opportunities for improvement. Agronomy Journal, v.110, p.1-37, 2018. https://doi. org/10.2134/agronj2017.02.0112

Oliveira, S. M. de; Almeida, R. E. M. de; Ciampitti, I. A.; Pierozan Junior, C.; Lago, B. C.; Trivelin, P. C. O.; Favarin, J. L. Understanding $\mathrm{N}$ timing in corn yield and fertilizer $\mathrm{N}$ recovery: An insight from an isotopic labeled-N determination. Plos One, v.13, p.1-14, 2018. https://doi.org/10.1371/journal. pone. 0192776

Parentoni, S. N.; França, G. E.; Bahia Filho, A. F. C. Avaliação dos conceitos de quantidade e intensidade de mineralização de nitrogênio para trinta solos do Rio Grande do Sul. Revista Brasileira de Ciências do Solo, v.12, p.225-229, 1988.

Pinho, R. G. von; Borges, I. D.; Pereira, J. L. de A. R.; Reis, M. C. dos. Marcha de absorção de macronutrientes e acúmulo de matéria seca em milho. Revista Brasileira de Milho e Sorgo, v.8, p.157-173, 2009. https://doi.org/10.18512/1980-6477/rbms. v8n2p157-173

Santos, L. P. D.; Aquino, L. A.; Nunes, P. H. M. P.; Xavier, F. O. Doses de nitrogênio na cultura do milho para altas produtividades de grãos. Revista Brasileira de Milho e Sorgo, v.12, p.270-279, 2013. https://doi.org/10.18512/1980-6477/rbms.v12n3p270-279
SAS - Stastistical Analysis System. SAS ${ }^{\bullet}$ University Edition. Cary: SAS Institute, 2018.

Schimel, J. P.; Bennett, J. Nitrogen mineralization: Challenges of a changing paradigm. Ecology, v.85, p.591- 602, 2004. https://doi. org/10.1890/03-8002

Silva, E. C. da; Muraoka T.; Buzetti, S; Trivelin, P. C. O. Manejo de nitrogênio no milho sob plantio direto com diferentes plantas de cobertura, em Latossolo Vermelho. Pesquisa Agropecuária Brasileira, v.41, p.477-486, 2006. https://doi.org/10.1590/S0100204X2006000300015

Silva, H. de S.; Carvalho, M. A. B. de; Souza, A. P. de; Barbosa, E. da S.; Pereira Neto, J. M.; Vieira, C. P. Distribuição espacial das raízes do milho submetido a adubação mineral em sistema de plantio direto. In.: Zuffo, A. M.; Aguilera, J. G. Solos nos biomas brasileiros 2. Ponta Grossa: Atena, 2018. Cap.3, p.17-27. https:// doi.org/10.22533/at.ed.0941814123

Soil Survey Staff. Illustrated guide to soil taxonomy, version 2.0. Lincoln, Nebraska, USDA - United States Department of Agriculture. Natural Resources Conservation Service, National Soil Survey Center. 2015. 681p.

Stanford, G. Rationale for optimum nitrogen fertilization in corn production. Journal of Environmental Quality, v.2, p.159-166, 1973. https://doi.org/10.2134/jeq1973.00472425000200020001x

Tedesco, M. J.; Gianello, C.; Bissani, C. A.; Bohnen, H.; Volkweiss, S. J. Análise de solo, plantas e outros materiais. 2.ed. Porto Alegre: Departamento de Solos da Universidade Federal do Rio Grande do Sul. 1995. 174p. Boletim Técnico de Solos, 5 